\title{
Echoes of Ecocriticism: An Introduction ${ }^{1}$
}

\author{
Cecilia Novero
}

\section{Stepping Stone: Art Works}

I wish to start this introduction by considering New Zealand artist Michele Beevors's incomplete series of installations that she names The Anatomy Lesson: Knitted Works (2005-2017). This work, I believe, superbly illuminates - indeed crystallizes - some of the key ideas and concerns that recent ecocriticism has borrowed from the new materialisms.

Succinctly: the new materialisms encompass provocatively rich interdisciplinary approaches to the humanities and the sciences. The manifold orientations that are gathered under this rubric share an ethical and political commitment to a return "to the fundamental questions about the nature of matter and the place of humans within the material world." 2 New materialisms aim to bring together in produc-

${ }^{1}$ Let me thank the participants in the GSA Seminar on Material Ecocriticism and German Studies (Washington D.C., 1-4 October, 2015) out of which this volume has arisen. In addition, I am grateful for the precious input of Nicholas Rennie, Anke Pinkert, Heather Sullivan, Peter Barton, Gustl Obermayer, Paola Voci, Bridie Lonie, Michele Beevors, and Gautam Ghosh without whom this volume could not have materialized.

${ }^{2}$ See New Materialisms: Ontology, Agency, and Politics, edited by Diana Coole and Samantha Frost (Durham, NC and London: Duke University Press, 2010), 5. That the new materialisms adopt the term 'materialism' in an unorthodox and, according to some critics, improper way is a point of contention among scholars in the humanities, but I believe this to be productive to all parties. Among other things, and perhaps counter-intuitively, such a controversial "reference" to materialism constitutes a call for ecocritics to ponder once again the relevance and impact for ecocriticism of socalled constructivism (the rather broad umbrella term under which quite distinct positions are often brought together indiscriminately, in my opinion, and without due attention). As far as material ecocriticism is concerned, this is true insofar as the latter, while embracing and incorporating new findings in science, cannot and does not wish to relinquish the concept of "text" - as 
tive new constellations earlier and on-going concerns about matter, the body, and corporeality - as these have been elaborated especially in feminist, cultural and political theory - with theories of matter as developed in the sciences (in particular, physics, biology, and ethology). Pillars in this context are Karen Barad, Donna Haraway, and Wendy Wheeler (see next section). Each one of these scholars in singular ways has emphasized the agentic forces of matter, a matter that acts in and co-constitutes the world, and that, for most scholars,

a differential material operation - that it places outside the purview of the human and within a larger than human context. (Jacques Derrida's work is relevant here but also Julia Kristeva's or Rosalind Coward's. Each would need to be reappraised, in different ways.) The discussion in the humanities about the divide between constructivism and realism (not determinism) has returned more forcefully now that nature has manifested itself powerfully and "unpredictably" through catastrophic events with enormous sociopolitical consequences, for example. Whether the new materialisms bridge the gap between nature and culture, or muddle the question of this divide; whether they offer genuine non-anthropocentric possibilities to know nature by acknowledging a human-non-human becoming with; or whether the new materialists thereby fall into the representational trap that confounds methods (subjects) and objects is the question that Vicky Kirby insightfully pursues, without closing it off, in "Matter out of Place." (See her edited volume, What if Culture was Nature all Along? Edinburgh: Edinburgh Press, 2017, pp. 1-25). The political stakes are high here for those (feminist, materialist, posthumanist) scholars who take seriously those outcomes of science that indicate how cognition might indeed be just another of those messy operations -such as metabolism--that are at work in the body itself. Cognition accordingly would be located in the body, a body that furthermore manifests as matter out of place, and this matter is, further still, unavoidably political (Kirby mentions the pharmaceutical industry). How to hold on to the distinction between nature and culture? "Can we risk" - Kirby closes -"the suggestion that nature, in essence, is 'under construction'?'” To which I would also add, in conclusion, a previous indirect question that Kirby also posed about ecocritical writing: "How we might write from a position that tries to acknowledge its immersion in/as an 'in-between,' no-thing can seem infuriatingly impossible, and yet..." (p. 19) Dada's and Walter Benjamin's "incorporative" acts of corporeal writing could function as a good, if challenging, antecedent to new "materialist" prose and thought -as I argue in my book Antidiets of the Avant-Garde: From Futurist Cooking to Eat Art (Minneapolis and London: University of Minnesota Press, 2010). 
is inherently "semiotically creative" thus "meaning making". This non-anthropocentric framework that posits humans as sharing the phenomenon of signification with the non-human has contributed to a new wave in material ecocriticism according to which, as Serenella Iovino puts it, "our world is a storied dimension emerging from the cooperation of nature and culture, of physical elements and discursive practices. The matter of the world, in the form of landscapes, ecosystems, and bodies is here read as a text expressing the interactions of human and non-human actors." 3

Ideas about human-non-human co-constitution and entanglements have become instrumental to ecocritics today especially because their interests lie in rethinking "nature" specifically from the framework of climate change, environmental degradation and biodiversity loss, all phenomena with amply unjust bio-political repercussions. Reflections on the non-anthropocentric creativity of matter also challenge material ecocritics to reconsider how exactly and with what effects the political agency of one's own labour of study - hence reading - one's own labour of storying - hence writing with - the world's own expressivity can indeed come to speak for this morethan-human world. Because art is able to "make sense," by crystallizing in one work the material, aesthetic and conceptual levels of understanding, it is to art that I turn now to better introduce the indissoluble intricacies of material ecocriticism that make this open and generous field so stimulating.

Anatomy Lesson: Knitted Works (2005-2017) comprises a series of installations, some of which were shown in the South Island of New Zealand (2015) in a show titled Wreck of Hope, from an eponymous work. [See insert with figures.] For the show, Beevors first closely studied, and reproduced in metal, skeletons of ordinary animals, i.e., horses, a dolphin, a turtle, and a snake (other creatures are still in the making). These are replicas of mundane beings - i.e., neither extinct nor endangered species (at least not yet) -, which Beevors has covered, in meticulously hand-knitted, bone-coloured wool.

\footnotetext{
${ }^{3}$ Serenella Iovino, "From Thomas Mann to Porto Marghera: Material Ecocriticism, Literary Interpretation, and Death in Venice" in Handbook of Ecocriticism and Cultural Ecology (Berlin: DeGruyter 2016), 350.
} 
In the Wreck of Hope exhibition, Beevors showed these knitted animal skeletons as emerging from or sinking back into platforms that agglomerate what Bridie Lonie describes in her doctoral thesis as "appropriated detritus from the industrialized carbon-heavy world." (Thesis, unpublished) Their bases are made of pieces of discarded domestic furniture that are trapped in a "rubbery bitumened island surface." 4

The Wreck of Hope points up the entwinement of scales - spatial and temporal, historical and biographical, historical and naturalhistorical, personal and political - that has emerged as a crucial knot when wishing to understand the unintended consequences of human action in the world. The work references Caspar David Friedrich's 1824 painting Sea of Ice, which was instigated by the aftermath of the shipwreck of William Edward Parry's expedition to the North Pole (1819-1820): of the ship only a few pieces remain visible through the ice that has engulfed them and thereby erected a natural mausoleum in memory of the departed. In Friedrich's painting the human "hope" of dominating nature - i.e., of finding an Arctic passage that would improve commerce and thereby eliminate the ice to make room for human traffic - has had the inverse effect: ice has encroached on the wreck of this ship and thereby reclaimed human history - as the tragedy of human hubris - for itself, thus absorbing history within the sublime spectacle of natural history. ${ }^{5}$

There is no ice (left) in Beevors's own resignification of Friedrich's Wreck; the installations are mounted, as it were, on the wreckage of that wreck, on the detritus of the detritus that commerce and accumulation have in fact left behind in actual seas of waste. These islands, as Beevors describes them, "resemble flotsam of the congealed plastic kind, floating off the coast of Miami, miles of plas-

\footnotetext{
${ }^{4}$ Michele Beevors, "The Wreck of Hope" in Catalogue of the eponymous exhibition in Oamaru, NZ at the Forrester Gallery, 12 December 2014 February 2015).

${ }^{5}$ Were this the occasion for a thorough ecocritical analysis of Beevors's series of installations, I would have to incorporate here the readings of Romantic "matter" as variously carried out in the texts of Heather Sullivan, Kate Rigby, Sabine Wilke among others. See the perforce synoptic discussion of their work in the next section.
} 
tic, fathoms deep; an island of shopping bags and Disney toys, an island without a name." (Beevors) The landscapes Beevors's platforms sustain or devour concern more than human death: they stand for the ruins of a historical life that has even deprived itself of a last chance, namely that promised by a return to natural history, that wreck of hope. The skeletons are accurate metal replicas of natural specimens, replicas that function as memories of fossils now bereft of a natural history that is no more. The viewer, in this interpretation, is left with a counter-sublime act of contemplation of absolute loss, a loss that is, furthermore, perpetuated as self-sustaining deathly presence. The effects of such an encounter between the viewer and the work may thus, at least initially, instigate melancholic feelings and a sense of inescapable doom. It is a feeling that resonates with some of the catastrophic accounts of climate change, or species extinction, which Anatomy Lesson both invokes and suspends. ${ }^{6}$

And yet, on a closer look, Michele Beevors's mounted and knitted skeletons surpass the temporality of inexorable catastrophic death, instead opening new equally urgent temporalities: these are the temporalities that accrue from the labour of mourning, as Lonie, referring to Beevors's own statements in this regard, implies. Such labour is essential both figuratively and operationally in Beevors's installations, where it manifests in the knitted "shell" or "skin" which protects these bones, and - even more crucially - in the physical labour, i.e., the energy and the hours spent in knitting: the labour of care that is also the labour of weaving together manifold time scales: the mundane and personal, the domestic and the historical, the natural historical and evolutionary, for example.

In Beevors's Anatomy Lesson, in short, the acts of knitting a new skin for these exposed and vulnerable skeletons of ordinary animals, and of clothing them, connect the different yet overlapping temporal and qualitative scales of personal, species and interspecies loss in a labour of care. Ordinary animals, not the extinct ones and not those threatened by extinctions, are cared for in their not yet terminal and

\footnotetext{
${ }^{6}$ On the ins and outs of disaster narratives, see Kate Rigby, Dancing with Disaster: Environmental Histories, Narratives and the Ethics for Perilous Times (Charlottesville: University of Virginia Press, 2015), 1-23.
} 
anonymous death, rather in a dying that binds each of them to the living labourer who knits her life in time to them. Beevors knits different, original, stiches for every individual animal skeleton, some stiches she invents ad hoc, i.e., for the specific vertebrae of the specific skeleton, so that each part of a skeleton receives the care that best suits it quite literally. Through their death, each animal is revealed as an individual being deserving of respect and attention, hence mourning. Their deaths are woven into the human world of loss(es), and by attending to their individual deaths in labour, the Wreck of Hope suggests, the human learns to mourn the death of another as her own, to expose herself to a shared death, to respond to loss, in and through an act of labour that is an act of interspecies love.

At the same time, these animals always hold within them the future anterior of mass extinction that the installations also suggest, in their balancing on the unstable islands of waste. They will have died en masse, and with them humans too, the installations intimate, if the acts of studying, knitting, weaving, labouring through the losses that humans and non-humans share are relinquished, in the present, for the care of the future. They will have become extinct, and the human with them, if the human gaze were to have turned inwards: driven by an anthropocentric and fetishistic melancholia if this gaze were to have persisted in disavowing vulnerability, death and loss. So, the call is to keep knitting. As the pedestals of domestic garbage, to which these skeletons are co-joined and to which, through them, we are too, remind us, no death here is purely personal, natural, human, and organic. The greatest care in dressing the skeletons is devoted first to the invention and later the making of the patterns that cover the "joints" of the animals: it is to these meeting points that hours of study and labour are devoted. Beevors leads the way with her intimate yet grandiloquent work of concentration, invention and devotion to these skeletons.

Beevors's installations ultimately remain standing despite the sea of fuel-fossil garbage that threatens to paralyze and absorb the mind and the body of its "subjects" - human and non-humans, viewers and sculpted animals alike. They stand because they are sustained by the challenging practice of study and attention that is rooted in the la- 
bour that is spent, and the care and time that are taken, to work through the history that has produced such debris. Beevors's knitted skeletons show that it is only through such practice that other material worlds may be imagined. The practice of worlding, to put it with Donna Haraway, cannot be innocent, and do away with history, loss, damage, power, injustice etc. ${ }^{7}$; in fact, worlding starts with working though - tracking, in David Harvey's words - the different kinds and scales of death and loss, time and space, that interlock in the "web of life." Harvey defines it as the "web of interconnections that make up the living world with all manner of unintended consequences." 8

The skeletons' unfinished, continuous knitting together of the personal and the collective, of human and non - human temporalities, and of the times of singular history with those of the return and renewal of natural history, is also momentarily frozen in time in the installations. This is the time of a present that bears within itself the possibility of emerging out of the "wreck of hope," out the seas of waste, hence out of the wreck of the wreck of hope - as the dolphin whose somersault is caught in mid-air hints at in the eponymous installation. Emergence, the Anatomy Lesson works suggest, hinges on the challenging practices of looking and taking care, looking with care and taking care to look, which all overlap in the (French) term "regard." This regard helps us to laboriously re-construct, track, and knit together the bones and threads of complex nature-culture stories. $^{9}$

${ }^{7}$ Haraway writes in one of her many definitions of "worlding": "What I mean is more like worlding in the $\mathrm{sf}$ [science fiction] sense, where earthly ontological choreography remains in play and at stake in living and dying with each other in our wounded, yet still capacious and capable, motley kinds. My open is to be found in play and in labour, where who and what are to be are forged in thick and deep times and places." See "Staying with the Trouble: Xenoecologies of Home for Companions in the Contested Zones," From the Cultural Anthropology website, July 27, 2010.

https://culanth.org/fieldsights/289-staying-with-the-trouble-xenoecologiesof-home-for-companions-in-the-contested-zones

${ }^{8}$ David Harvey, Spaces of Hope (Berkeley: University of California Press, 2000), 219.

${ }^{9}$ Emergence is a key term that ecocritics have borrowed from Raymond Williams's influential work, especially Marxism and Literature (Oxford 
When asked by Giovanni Aloi what role art plays in his philosophical endeavours, Cary Wolfe reported that art, for him: "can undertake what I call 'non-propositional conceptualization' of the kinds of questions we are interested in and in ways that the relatively impoverished medium of language and textuality really can't. That makes art's engagement of, say, the question of species loss and extinction potentially more multi-dimensional, if less precise, than theoretical exposition in the medium of words." Wolfe paraphrases Niklas Luhmann when he continues to say that "in art - and this includes literary art, of course - things that don't make sense make meaning, and it's possible for elements that are not present to be maximally meaningful."10

Following in the tracks of Wolfe, I started with Beevors's Anatomy Lesson: Knitted Works (2005-2017) because - in my view - this series of installations suggestively, affectively, and meaningfully unlocks at least some of the key philosophical concepts that engage material ecocritics. The installations are able to reveal the complexities and contradictions that constitute the challenge, e.g. the labour, of thinking through the many facets of human-non-human interactions and contact zones in the present age of global climate change, mass extinctions, intensive animal farming, and pandemics. ${ }^{11}$

and London: Oxford University Press, 1977). In its appropriations, however, the term has been inflected so as to speak to those non-human concerns ignored by Williams.

${ }^{10}$ Cary Wolfe, interview by Giovanni Aloi. Antennae: The Interview Issue \# 1, 38 (Winter 2016): 7.

${ }^{11}$ Haraway has variously spoken of "contact zones." Most recently she put it thus in a conversation with Cary Wolfe: "The main point is that insofar as biopolitics is concerned, this question of ecosystem assemblages is the name of the game of life on Earth. Period. There is no other game. There are no individuals plus environments. There are only webbed ecosystems made of variously configured, historically dynamic contact zones. With the help of my colleague-friends Karen Barad and Scott Gilbert, sometimes I name this intra-active and diffractive complexity." Donna Haraway and Cary Wolfe, "Companions in Conversation" in Manifestly Haraway by Donna Haraway and Cary Wolfe (Minneapolis and London: University of Minnesota Press), 249-250. 
Beevors's Anatomy Lesson prompts critics and artists alike to keep labouring, knitting threads, and in doing so, to pay attention to detail - work which involves resourcefulness and inventiveness in their acts of study, and reading the world. Through the hard labour of knitting across disciplines and across species alternative dynamics of living and knowing can be imagined that will hopefully yield to a more socially equitable and environmentally sustainable distribution of biopower.

\section{In the Thick of it: Complex Concepts for Complex Worlds}

Beevors's series of installations, and their eloquent title, poignantly embody and amplify some of the staple questions and concepts that have informed the most recent theoretical positions of ecocritics, such as those emerging within the "new materialisms." I have in mind questions of human and non-human agency, the "being" and creativity of matter (onto-epistemology), and the relations between history and natural history among many others, as mentioned above. Beevors's own sculptures help to demonstrate how much questions about the positioning and acting of humans within a larger than human environment have triggered artists and writers alike to conceive of the complex, imaginative aesthetics of naturecultural entwinements.

Naturecultures, a term introduced by Haraway, indicates the deep entwinement of human and non-human factors that has characterized and continues to characterize the co-evolution of species - hence life in its biological and cultural diversity. It is a question of whether, for example, one considers microbes, fungi, or dogs in relation to humans. Epistemological and ontological issues are of course at stake when naturecultures become the framework for approaching the world and its knowledge, and Haraway's insistence on the awareness of the "impact" that one's own situated knowledge has on that very process of knowing and the objects it considers is here key. Indeed, those objects - in naturecultures - are never purely constructed nor unchanging objects, unsusceptible to the doings of humans and non- 
humans. In knowing in all its forms - including practices or "doing", from dog-training to bee-keeping etc. - objects are responsive and objects change - indeed, objects turn into "actants" (Bruno Latour) as do the subjects of knowledge. They exist in mutual relations of becoming, a becoming with, as Haraway explains. This act of on-going co-constitution grounded in mutual responsiveness also translates, in material ecocritical writing, into the communicative energy - alternatively called semiotic, textual, or narrative - that moves (animates) all matter through time. When knowledge in all its practices acknowledges "response" as one of its tasks and goals, in short, is able to respond to response, and in the act makes itself "responsible" - as in "able to respond" - towards the changing relations that ensue, then a flourishing is the outcome. Such situated practice of knowing - a being in the world that worlds and is in turn worlded - is diffractive, and always considers relations as mutually changing encounters or, in common ecocritical idiom, "intra-action." (Karen Barad has adapted the term from her reading of Niels Bohr's principle of 'indeterminacy'.) ${ }^{12}$

The term naturecultures is one of those signature terms that - now common currency in ecocritical and animal studies -have helped to consider agency outside the purview of anthropocentrism, without requiring cultural history to be either harmonious or catastrophic. Instead, the term harnesses the power of human knowledge and curiosity to cultivate a co-existence with the changing, mutable, and multiple but also vulnerable world which human and non-human inhabit.

Modulated through actor-network theory, naturecultures, and biosemiotics, the non-anthropocentric idea of an extensive, distributed agency - more commonly referred to as diffraction or intra-action constitutes a challenge when pursuing ecocritical readings of texts (whether literary, artistic, cinematic) as well as readings of the world. Iovino makes clear that reading the texts or stories that have been and are constantly being inscribed in matter (as it manifests itself in

${ }^{12}$ For an explanation of the term, see Barad in Rick Dolphijn and Iris van der Tuin, New Materialism: Interviews and Cartographies (Ann Arbor: Open Humanities Press 2012), 48-70. 
its long-standing entanglements with the human world) is one kind (of) response-ability that humans can learn to practice, individually and collectively. The world expresses itself in signs that - as texts humans can carefully translate into their shared practice of storytelling. Iovino remarks that humans cannot speak as matter but can give form to the expressivity of matter by carefully translating this into stories that "make sense" to us and make a difference in the world. In this way, if aware of their positionalities, of their strategic, but also provisional locations as narrators or rather perhaps translators, humans can speak for matter, in Iovino's view. Iovino offers illuminating examples of how to read diffractively specific territories' textualities, for example, when she examines the cities of Venice and $\mathrm{Na}$ ples, through the lens of these cities' "natural dynamics, cultural practices, political visions, and industrial choices" as they interlace with human bodies in issues of justice, health, and ecology." 13

As per the above concept of diffraction, then, such acts of reading translate the traces of direct or unintended human interventions in the world, as well as the effects of nature's responses to human exploitation or abuse of nature, into stories that matter (speak) to humans, and they leave a trace -in which time always remains to be seen. Such diffractive ways to read matter, which cannot be extricated from intertextual acts of writing and rewriting, instigate, safeguard and enhance "flourishing"(of stories and storied worlds). Flourishing occurs precisely as the practice of exposing the knots and junctures that sustain such narratives and in this act they make insoluble ethical and political complexities their topics and their focus, thus requiring more knowledge, more imagination, more responsibility.

\footnotetext{
${ }^{13}$ Iovino, "From Thomas Mann to Porto Marghera," 349.

${ }^{14}$ Franklin Ginn, Uli Beisel and Maan Barua explain the term "flourishing" thus: "Flourishing can be described as an ethic which enshrines life's emergence and the prospects or conditions for life's emergence as the good to be upheld or nurtured. ... Haraway, meanwhile, has argued for an ethic of multispecies co-flourishing in which the outcomes are never certain, ethical judgments stick close to the action of worlding rather than abstract principles, and in which emotion and reason both play their parts. We also know, from the thorough working of biopolitics in recent years, that life and death are not polar opposites, but forces that circulate through the same spaces
} 
Here, ecocritics have been diligent in paying their dues to postcolonial studies, as Ursula Heise, Axel Goodbody, Serpil Oppermann, Kate Rigby and others have noted. The stories of resilience of indigenous populations, the many distinctive semiotic systems that these cultures have developed in order to relate to and with their environment are taken as lessons in alternative aesthetics for living ethically, and sustainably.

The notion of distributed agency that is rendered in ecocritical theory through the term diffraction is further backed up in ecocritical approaches by theories advanced in biosemiotics (especially in Wheeler's formulations) according to which matter - not just organic but also abiotic - is informed by the drive, indeed some claim telos, to communicate. ${ }^{15}$ At all levels matter strives towards it, we are instructed, not just humans and life forms in general. Supported by research in the sciences, ecocritics have had recourse to the view of a semiotic universe, in other words the copying and coding of infor-

and bodies. Flourishing is not some 'soft' alternative to biopolitics. Flourishing always involves a constitutive violence; ... this perspective requires us to see nonhumans not always as victims, nor humans (or more accurately geographically and historically specific groups of humans) as perpetrators. Thus flourishing makes no claims to innocence or universality, asking instead who lives well and who dies well under current arrangements, and how they might be better arranged. " (114-115) See Ginn, Beisel, Barua, "Flourishing with Awkward Creatures" in Environmental Humanities, 4 (2014).

${ }^{15}$ See Wendy Wheeler, The Whole Creature: Complexity, Biosemiotics and the Evolution of Culture (London: Lawrence \& Wishart, 2006). "Wendy Wheeler draws on the new field of complex adaptive systems and biosemiotics in order to argue that - far from being opposed to nature - culture is the way that nature has evolved in human beings. Her argument is that these evolutionary processes reveal the fundamental sociality of human creatures, and she thus rejects the selfish individualism that is implied both in the biological reductionism of much recent evolutionary psychology, and in the philosophies of neoliberalism. She shows, instead, that the complex structures of biosemiotic evolution have always involved a creativity which is born from the difficult but productive phenomenological encounter between the Self and its Others." See, endorsement online. At:

http://www.thethirdwayofevolution.com/people/view/wendy-wheeler (accessed on May 10, 2017). 
mation which involve repetition but also variation (e.g., differentiation). This information has served ecocritics to reframe and reposition the notion of creativity away from anthropocentric interpretations even more emphatically. At the same time, it has allowed ecocritics to preserve the distinctiveness of the multifarious human acts of creation, from language in general to the multifaceted yet specific forms of artistic expression human language takes. This, however, is not to the detriment of other linguistic worlds but, rather, in support of such a plurality of languages, within a single "logos of the living world" in Rigby's formulation. In Rigby's discussion of Westling, she writes that the latter argues for the "continuity of articulate human speech and writing with those semiotic processes that are now being discovered within and among all other systems." Human language is understood, in line with Merleau-Ponty, as "the manifestation of an inherently meaningful universe."16

Some German critics or critics working in German Studies, like Gernot and Hartmut Böhme, Hubert Zapf and Rigby (art historian Horst Bredekamp could also be included) have had reason to mine German Romantic ideas of life and art in particular - as well as the reappraisal of these ideas in the works of $20^{\text {th }}$ - century critical theory - to weave singular aesthetic approaches in ecocriticism. ${ }^{17}$ They have, for example, revisited poetic theories about nature's language (Natursprache and Poesy), and the ethical and political implications of these ideas for the environment today as these play out in literary texts. In another strand of thought, the emphasis has fallen on the role of aesthetics in natural philosophy (Naturphilosophie, for example in Goethe, Alexander von Humboldt but also Charles Darwin). Here connections between straightforward science, biosemiotics and Romanticism are noted. ${ }^{18}$

\footnotetext{
${ }^{16}$ Kate Rigby, "The logos of the living world: Merleau-Ponty, animals and language" in Green Letters, 18:3 (2014): 332-334.

${ }^{17}$ See also Robert J. Richards, The Romantic Conception of Life: Science and Philosophy in the Age of Goethe (Chicago: Chicago University Press, 2002).

${ }^{18}$ For example, Louise Westling writes: "We are no longer alone as transcendent Minds locked in decaying bodies on an Earth where we don't belong, and separate from the myriad creatures around us. Now we can see
} 
Other ecocritics, like Iovino, have strategically employed the communicative agency of the nonhuman realm to concentrate on its narrative aspect. Iovino uses the term story, or rather the process of storying the world, as the process of translating into human language the world's acts of self-expressions that, she insists, are always already entangled with those of humans. Above all, creativity in its various ecocritical fashions has been deployed as itself the metaphorical operation through which ecocritics have addressed the knotty issue of mediation. Having invoked the trope and operation itself of creativity, and thereby the sister metaphors of story and/or translation in the first place, mediation (or its 'negation') has returned to "matter" to ecocritics, and their readers. Here I refer to mediation between text and world, human and non-human, but also between the movements between scientific and qualitative knowledge. With the resignification of ideas such as creativity, semiotics, meaning, narrative that has found support in biosemiotics, and other sciences, ecocritics have answered early critiques about their initially undertheorized approaches to nature in their texts, which had fallen into the fallacies of representation. Since these critiques of early ecocriticism, poststructuralism and theories of bio-politics have indeed been partially reassessed and taken up for consideration in ecocritical readings, as Serpil Oppermann and others have pointed out. Some ecocritics have acknowledged the political investments of such theories, and have investigated further the implications of, for example, the work of Julia Kristeva, Jacques Derrida, posthumanism (Cary Wolfe), animal studies, and feminist phenomenology (Elizabeth Grosz) for thinking the complexities of materiality in and beyond the literary text. Dynamics of power-knowledge and biopower, in their variants from Michel Foucault via Giorgio Agamben, to Judith Butler, Hara-

ourselves as vibrant bodies pulsing in harmony with our whole environment. This is what the new science is telling us. As human animals we live in symbiosis with thousands of species of anaerobic bacteria." (36) See Westling, "Literature, the Environment, and the Question of the Posthuman" in Nature in Literary and Cultural Studies: Transatlantic Conversations on Ecocriticism, edited by Catrin Gersdorf and Sylvia Mayer (Amsterdam: Rodopi, 2006), 25-47. 
way and Wolfe, Eric Santner and Carlo Esposito, (amongst others) are clearly at work in contemporary material ecocriticism. Iovino's entire body of work, Heather Sullivan's engagement with "dirt", in addition to her short essays on the "dark pastoral," as the latter is reconceived through the trope of "dirty traffic" (to my knowledge, one of the very few essays in the ecocriticism of German texts that takes up questions of labour), and Christopher Schliephake's Urban Ecologies are a case in point. ${ }^{19}$

Both Sabine Wilke's review of contemporary ecocritical trends as these merge with the environmental humanities and Oppermann's 2015 edited volume New International Voices in Ecocriticism make abundantly clear that ecocriticism is a distinctive, theoretically engaged, field rather than a method, which consciously chooses to keep its geopolitical, conceptual and ontological borders open in its pluralistic evaluations of texts and ideas. ${ }^{20}$ No single environmental genre therefore is the object of ecocritical engagements, as no single "nature" exists for ecocritics. The plurality of approaches that now include studies from non-Western countries has meant that issues of environmental justice, such as those of toxin-related diseases, avian influenza or radiation after Fukushima, etc. have become more prominent in ecocriticism. Oppermann's edited volume testifies to this through its transnational scope, which also aims at the incorporation of emerging voices from, for example, Korea and Japan, in the hope fostering more academic egalitarianism. It is in this spirit that

\footnotetext{
${ }^{19}$ See Heather Sullivan, "Dirt Theory and Material Ecocriticism," in ISLE: Interdisciplinary Studies in Literature and Environment 19, no. 3 (2012): 515-531; and "Dirty Traffic and the Dark Pastoral in the Anthropocene: Narrating Refugees, Deforestation, Radiation, and Melting Ice" in Literatur für Leser, 14 (2014): 83-97. See also, Christopher Schliephake, Urban Ecologies: City Space, Material Agency, and Environmental Politics in Contemporary Culture (London: Lexington Books, 2017). The author argues that culture is an active component and integral factor within urban ecologies.

${ }^{20}$ See Sabine Wilke, "German Ecocriticism and the Environmental Humanities," GSR, 38, no. 3 (2015): 635-652; Serpil Oppermann, "Introduction," in New International Voices in Ecocriticism, edited by S. Oppermann (London: Lexington Books, 2015), 1-24.
} 
this volume of Otago German Studies welcomes the work of newcomers to the field.

It is my hope, in conclusion, that the broadening of this field in multiple directions all at once - including forays into theories previously marginalized such as the French feminism of Kristeva and Luce Irigaray, or the work of Mikhail Bakhtin, and deconstruction will continue. If complexity is the challenge that ecocritics welcome in their approaches to the world as text and vice versa, namely to the text as an act of worlding-terraforming, then more complex readings of the "political" legacy of, for instance, so-called constructionist theories as well as of the Frankfurt School, must persist. ${ }^{21}$ These cannot but enhance the ways ecocritics engage the meaning of histo-

${ }^{21}$ An exception is the insightful recourses to Theodor W. Adorno that are to be found in Kate Soper's research. See-for example- "Unnatural Times: The Social Imaginary and the Future of Nature" in The Sociological Review, 57 (2009): 222-235. Media theory is another scholarly area that has not been taken up by ecocritics in spite of its focus on materiality, possibly due to its resistance to narrative, as for example is evident in Friedrich Kittler's work. Just now, in 2017, a new series however has been launched by Bloomsbury Publishing devoted to "Media Matter". See:

http://www.bloomsbury.com/us/media-matter-9781628923841/ (accessed on May 10, 2017).

I thank Paul Dobryden for sharing this thought at the GSA seminar, in 2015. Analyses of environments inspired by biopolitics have been carried out in the environmental humanities. The journal bearing the eponymous title showcases numerous such engagements. Stephanie Rutherford's book Governing the Wild: Ecotours of Power (Minneapolis and London: University of Minnesota Press, 2011) is one text that takes up Foucault's idea of governmentality that helps integrate nature, power and profit. Rutherford examines film (An Inconvenient Truth by Al Gore) through this lens. Schliephake also includes the analysis of films, from The Wire (TV series) to Fritz Lang's Metropolis. His take is informed by the film's presentation of urban spaces that change "face" in response to human -non-human interweaving actions. An early call to consider the impact that poststructuralist theories might have for ecocriticism, prior to the new materialisms, came from Patrick Murphy, Literature, Nature and the Other (Albany, NY: SUNY Press, 1995). His call was taken up in Axel Goodbody and Kate Rigby's edited volume, Ecocritical Theory: New European Approaches (Charlottesville and London: University of Virgina Press, 2011). 
ry in relation to natural history, and the relations among the cultural, the planetary, and the environmental that, as Dipesh Chakrabarty reminds us, have come into relief especially with climate change. They would enrich even further the current set of expanding cognitive tools and help to keep the limits of the (onto)epistemological framework in sight that is so dear to material ecocritics, while at the same time fostering a whole range of self-reflexive questions about "writing" and the various aesthetics of ecocriticism itself. The knotted issues of mediation and representation that have re-emerged in ecocriticism so forcefully because and in spite of its diffractive methods of analysis could be turned into auspicious occasions to keep this interdisciplinary practice of approaching the world as text and in texts open to its own continuous diffractions. ${ }^{22}$

In this regard, and in spite of the new exciting publications that are continuously coming out, ${ }^{23}$ I therefore wish to close this section by

${ }^{22}$ Here both the work of Greg Garrard and especially Greta Gaard are of interest, as Nicole Thesz argued in an unpublished paper presented at the GSA 2015 in the seminar devoted to material ecocriticism. The former reminds us, as Thesz put it on that occasion, that ecocriticism allows us to take an interdisciplinary position in analysing the "rhetoric" shaping environmental debates and environmentalist discourse, which are part of literature, science, and metaphysics, among other disciplines. Gaard, for her part, brings up, in her work on Buddhism and material ecocriticism, the notion that the activity of narrative itself might be included in the critique. Contrary to the tendency to value narratives as modes of human expression (including in the context of visual narratives, e.g., monuments, film, and cityscape), Thesz continued, Gaard suggests that narration could be a distraction to insight and perception (Gaard 297). Thesz, unpublished paper, p. 7. See Greg Garrard, Ecocriticism (London: Routledge, 2012), 10; Greta Gaard, "Mindful New Materialisms: Buddhist Roots for Material Ecocriticism's Flourishing" in Material Ecocriticism, edited by Serenella Iovino and Serpil Oppermann (Bloomington: Indiana University Press, 2014), 291300 .

${ }^{23}$ In the European context, the journalEcozon@: European Journal of Literature, Culture, and Environment that was founded in 2010 devoted its first volume to "New Ecocritical Perspectives: European and Transnational Ecocriticism." The published essays were preoccupied with developing sustained ecocritical methods which focused on the different national and linguistic traditions. Oppermann's 2015 volume responds to this. 
renewing two of Ursula Heise's (et. al.) calls from 2011: i.) while welcoming all knowledge from as many fields as possible - the more the better! - ecocriticism must not tire of pressing the case for the "importance of the qualitative thinking practiced by environmental humanists"; and, jointly, ii.) address head-on "the issues of aesthetic form and its functions", including the relevance of experimental forms that are not overtly connected with the natural world, and the styles that ecocritcal writing/art takes. ${ }^{24}$ Both points are relevant for all those ecocritics and ecoartists who are invested in facilitating the emergence of structures of feelings attuned to the material processes of co-constitution in life, in science and in art.

\section{Trails: The Texts, the German Contexts}

The idea for this volume came from a seminar on material ecocriticism that was held at the 2015 meeting of the German Studies Association (USA), in Washington D.C, and organized by Emily Jones (a contributor here) and Seth Peabody. At that time, a group of scholars and students of German gathered to scrutinize specifically, from the critical concepts illustrated above, the new materialist interpretations of "matter" and "agency". How to produce ecocritical writing that might be consistent and expressive of the intellectual and political positions expounded theoretically was an urgent concern. The question asked was, in short, how to "do" ecocriticism when reading texts in German. Many positions taken by the scholars cited here functioned as a launching board for new readings of German modernist artwork, literary texts, and the cinema industry that were initiated on that occasion.

Among those, four are published in revised form in this volume: the articles by Jillian DeMair; Kiley Kost; Emily Jones and Sandra Kohler. These four essays examine, respectively: Annette DrosteHülshoff's poem Die Mergelgrube (The Marl Pit); Peter Handke's Versuch über den Pilznarren (Essay on the Mushroom Hunter,

${ }^{24}$ Lawrence Buell, Ursula K. Heise, and Karen Thornber, "Literature and Environment," The Annual Review of Environment and Resources, 36 (2011): 435. 
2012); contemporary novels by Tanja Dückers, Jenny Erpenbeck and Judith Schalansky; and an investigation of the role that non-human animals play in W.G. Sebald's narratives. Of the remaining three essays, Sabine Nöllgen examines food production in Austrian director Nikolaus Geyrhalter's documentary film Unser täglich Brot (Our Daily Bread, 2005); Joela Jacobs looks at German practices of recycling through the lens of migrants and refugees who recently relocated to Germany; and André Krebber closes the volume with the proposal that ecocritics reconsider Adorno's negative dialectics for its implications for the concept of nature that ensues. Accordingly, nature, negatively conceived, translates as the historical negation of instrumental reason. The open moves of negative dialectics - on Krebber's view - rescue nature without ever fixing it into an ahistorical object.

Some of the specificities of the German-speaking literary scenarios that German Studies scholars have taken to investigate through the cultural ecocritical lens - for example the troublesome notion of Heimat - have been noted beyond German eco-criticism. Indeed, this ecocritical revisitation of the Heimat idea prismatically complicates the notions of place-belonging, regionalism, and memory that have informed Anglo-American ecocritical readings. In turn, readings of German literature and film on the topic of Heimat have not been blind to the "spatial turn," and the international and interdisciplinary examinations of literature that emanated from it. Thereby both literature and ecocriticism in German have gained more weight with a broader global audience invested in questions of space.

Axel Goodbody's overall work and specifically Rigby's and Goodbody's 2011 edited volume on European Ecocritical Theory have made plain the relevance and scope of the German contributions to the field of transnational ecocriticism. The scope of that volume is especially broad in that it comprehends essays that span system theory, actor-network-theory, phenomenology, postmodern theory, Walter Benjamin, and Mikhail Bakhtin, to mention just a few approaches. Here, much groundbreaking work was done to cross the theoretical borders at hand, and also rub one approach up against the other. 
Returning to the trope of Heimat recurrent in German ecocritical studies (as this trope matters to at least two of the essays in this collection), Goodbody's own reflections on this trope offer a sophisticated theoretical apparatus at the intersection of themes in German literature and philosophy, such as Heidegger's notion of dwelling. In Nature, Technology and Cultural Change in Twentieth Century German Literature: The Challenge of Ecocriticism (2006), for example, Goodbody blends Heidegger's idea of poetry as a form of dwelling, with Anglo-American ecocriticism's own appropriations, most explicitly, through Jonathan Bate's poetics of human habitation within nature (Song of the Earth), and Rigby's understanding of dwelling as "an achievement, something which we have to learn again and again." 25 Goodbody unhinges place from Heimat and develops an "ecological aesthetics of poetry that appears to be the means of combining ethics and metaphysics. “26

Heimat becomes especially crucial in Goodbody's essay on Jenny Erpenbeck's novel Heimsuchung (Visitation, 2008). In his analysis, Heimat becomes the site of a "potential reconciliation of humans and nature.” In Goodbody's view Erpenbeck's text achieves this precisely because the text posits Heimat as temporary. ${ }^{27}$ In our present volume, Sandra Kohler also analyses Erpenbeck's novel, taking her cue from Goodbody's own work at the junction of ecological sensibility and collective memory. However, framing the novel within a poetics of memory-objects that she appropriates from Maurice Halbwachs (not unlike Goodbody), Kohler ultimately disagrees with Goodbody's conclusions as far as Heimsuchung is concerned.

While Heimat in the novel is subject to different acts of historical mourning, and in the labour and process of mourning is deterritorialized, according to Kohler these acts of mourning remain incomplete, or rather are blocked, and thus revert to melancholic states that finally provoke a human retreat from nature. Rather than entangling

${ }^{25}$ Axel Goodbody, "Heimat and the Place of Humans in the World: Jenny Erpenbeck's Heimsuchung in Ecocritical Perspective" in New German Critique 43 (October 2015): 10.

${ }^{26}$ Serenella Iovino, Besprechungen, 371. www.academia.edu (accessed on April 30, 2017).

${ }^{27}$ Goodbody, "Heimat”, 10, 16. 
themselves with the other-than-human, humans turn nature into an external object that helps them remember. This is so, for Kohler, despite - or in fact precisely because of - the crucial role that the backdrop of natural history plays in this historical novel. The analysis of Tanja Dückers Der längste Tag des Jahres (The Longest Day of the Year, 2006) and Judith Schalansky's Der Hals der Giraffe (The Neck of the Giraffe, 2011), in conjunction with the examination of Erpenbeck, leads Kohler to conclude that while these novels' characters exhibit a sense of place-identity and a caring attitude for nature, they don't translate such attachment into any favourable action towards the environment. This is so in spite of the fact that memoryobjects are connected to the natural environment in one way or another in the texts. Heimat is central to the characters' development in these works: alas, in Kohler's view, it ultimately translates into idealizations of locations, plants and animals. The latter are, for example, exoticized. Kohler in the end returns to Goodbody's notion of nostalgia. She closes her essay by pointing out that the novels under scrutiny enact a governance of ecosystems that instrumentalizes nature in the name of a human aesthetics which, de facto, appeases human loss through nostalgia and serves human fulfilment.

The core of DeMair's essay is the creative function that the Findlinge - rocks referred to in English as "erratics" - take in Droste Hülshoff's poem "Die Mergelgrube" (The Marl Pit, 1842). This focus leads DeMair to argue that Droste in fact challenged the idea of Heimat to which her work has been anchored in German literary criticism. Droste's scepticism that being rooted in the soil fosters harmony with the landscape becomes evident if the "Marl Pit" is examined through the lens of Droste's interest in the geological history of the earth and the place humans take in it. This is the perspective from which DeMair approaches the poem. Her point is to show that the mysterious erratics function less as a source of literary inspiration in Droste's and Goethe's texts than as objects of scientific inquiry which, further, are discovered to bear their own creative potential. Referencing first Sabine Wilke and then Zapf, DeMair writes: "Although the present analysis inevitably approaches 'creative matter' through human creativity, it aims to recognize the particular ways in which Droste-Hülshoff and Goethe depict the creative process in 
nature which - like human creativity - is one component intertwined with broader natural structures." (qtd.) As DeMair shows, in studying these rocks and their geological history, Droste-Hülshoff and Goethe point up the ways in which erratics in particular have participated in interconnecting natural with cultural forces. Following Iovino and Sullivan, DeMair remarks that by having their lyrical subjects physically experience the seismic shifts of the earth, DrosteHülshoff and Goethe make the case that creativity is a coconstitutive process of inscription, tracing - in short, writing- that is shared by humans and non-humans alike, as Rigby puts it. Following in the footsteps of Rigby's own "reconsideration of Romantic-era engagements with the interrelationship between natural becoming and poetic communication," DeMair's essay, too, contributes to the "as-yet- small body of work that is beginning to explore the Romantic antecedents and affiliations of biosemiotics.",28

Peter Handke's Versuch über den Pilznarren (Essay on the Mushroom Hunter, 2012) is the most illuminating example of coconstitutive writing among the texts considered in this volume. In Kost's rendition, "Handke tells a story of mushrooms from the point of view of one human who appears to be uninhibitedly caught up in their world." (qtd.) Indeed, what Kost then sets out to demonstrate is that the mushrooms become so entangled with the human story that it is impossible to separate their story from that of the human, as well as writing from the material operations of and across bodies. Here Kost invokes Stacy Alaimo's notion of trans-corporeality according to which the substances that permeate all living bodies not only travel in the body but also " $d o$ things - often unwelcome or unexpected things." ${ }^{29}$ Handke himself speaks of mushrooms' threatening coconstitutive agency, in a conversation with Alessandra Iodicicco: "They are devils! If you are not careful, they grow in your house, they putrefy, and worms crawl all around them... they drive you cra-

${ }^{28}$ Rigby, "Art, Nature and the Poesy of Plants in the Goethezeit: A Biosemiotic perspective" in Goethe Yearbook, 22 (2015): 24.

${ }^{29}$ Stacy Alaimo, Bodily Natures: Science, the Environment and the Material Self (Bloomington: Indiana University Press, 2010), 146 (qtd). 
zy. I wrote this down." ${ }^{30}$ It is a critic's task then, according to Alaimo, to track these material journeys, and ponder the effects of these travels, which translates in Handke's texts into following the mushrooms' writing. Indeed, due to the biopolitics of our time, bodies are now the centre of practices and actions that, if not political before, certainly are now.

While Kost does not explicitly draw the ethical - political implications of Handke's co-writing with the mushrooms, she does retrace the text's sprawl of references to mushrooms' imbrications in the cultural and political, as well as economic histories. For example, Kost has recourse to Anna Tsing's study of the highly sought-after matsutake mushroom. ${ }^{31}$ In her essay, Tsing demonstrates how every aspect of this fungus is interconnected with intersecting practices of worlding. These include: more or less contaminated forests, parasites, chemicals, migratory routes, and market quotations. By embedding Handke's writing within other myriad practices that emanate symbiotically from these spore-bearing fungi, Kost steers her text away from author-focused readings. Via Tsing, she demonstrates that Handke's story of the resistance that his unruly, non-cultivable mushrooms put up against marketability, which the text suggests metaphorically stands for Handke's kind of untimely writing, that this story is reabsorbed from within the larger stories of human and non-human resilience alike under global capitalism. Kost concludes that if the mushrooms are, for Handke, the stepping-stone to a close scrutiny of the inner workings of writing, the outcome of such scrutiny is that writing cannot be disentangled from the material networks out of which it springs and into which it flows. Thus, the practice of mushroom-hunting morphs into a kind of mushroom-writing which is endowed with the epic faculty to heal the body and nourish the imagination that is the mushrooms' very creative property.

\footnotetext{
${ }^{30}$ Alessandra Iodicicco and Peter Handke, "Handke: Vivo nel bosco, ascolto gli alberi che sussurrano," in Il Corriere della Sera, n. d. and n. p. n. http://lettura.corriere.it/handke-vivo-nel-bosco-ascolto-gli-alberi-chesussurrano/ (accessed on May 8, 2017).

${ }^{31}$ Anna Tsing, "Unruly Edges: Mushrooms as Companion Species," in Environmental Humanities, 1 (November 2012): 141-54.
} 
If the gaze of the "fool for mushrooms" (as I would call the "Pilznarr") falls in line with his nose, so to speak, and turns down towards the humus of the forest to find its illumination, the gaze of W.G. Sebald's characters turns inwards, so that the other-than-human functions as the anthropological machine. This is an optical device that as Giorgio Agamben theorizes- through its operative inversions constantly produces human life as separate from animal life. ${ }^{32}$ In her essay "Animal Encounters and Ecological Anxiety in W.G. Sebald," in this volume, Jones closely analyses animals in captivity in Austerlitz and Die Ringe des Saturn, non-domesticated animals both dead and alive in Nach der Natur, and the taxidermied bodies of animals throughout his works. Through her examinations she shows, first, how non-human animals in this author's texts are indeed framed as others, or otherwise fall outside the frames of human life as "bare life." Second, however, Jones complicates this interpretation by arguing that "in Sebald's texts, many of the human-animal interactions reside in [this] border territory. What seem at first to be metaphors or projection screens for the human subject's psychological state become with time and engagement subjects unto themselves, animals observing humans rather than the other way around." (qtd.) In contrast to readings of Sebald that focus on the erosion of history by natural history in his works, and the ensuing prevalence of a melancholic, if not tragic, sensibility with regard to the loss of nature, Jones enlists a whole array of material ecocritical approaches and perspectives developed in animal studies to insist that Sebald's narrators rebel against their own anthropocentrism, thus existing in a state of "ecological anxiety." She invokes Bakhtin's "transgredience" to underscore the kind of "self-othering" that Sebald's characters undergo in their encounters with non-human animals: "The effort on the part of Sebald's narrators to regard animals as individuals and to leave open the possibility of their subjecthood and material agency implies precisely this kind of self-objectification." She concludes that these instances point up the precarity of animal life in the context of human degradation of the environment. (qtd).

\footnotetext{
${ }^{32}$ Giorgio Agamben, The Open: Man and Animal (Palo Alto: Stanford University Press, California, 2004).
} 
Non-human and human animals are in the end redeemed in their reciprocal encounters - gazes - in Sebald's texts. No one is left unscathed in the documentary film that is the subject of Nöllgen's analysis, Austrian filmmaker's Nikolaus Geyrhalter Unser täglich Brot (Our Daily Bread, 2005). The film takes an unflinching and disturbing look at contemporary industrial food production -including factory farming, and the fast-paced industrial slaughter of millions of animals - across the world. As Nöllgen argues, the documentary pivots on precisely an aesthetics of looking that aims to bring into visibility, in front of the consumers' eyes, all that the eye prefers not to see. However, most importantly, the documentary - which was shot in high definition digital video - dispenses with most of the techniques that are typical of documentaries: no voice over, no translations of the spoken words, no mention of the several European locations where it was shot. This dispensing of voice-over coupled with long tracking shots, as well as the long-held frames, compels acts of contemplation - of vision - of what the food industry and consumers have relegated to invisibility through a plethora of commercial images. Nöllgen labels Geyrhalter's approach an aesthetics of renunciation or subtraction (Verzicht). Following Nöllgen's close readings, this operation, which, as she argues, manifests especially as human Sprachlosigkeit, is pursued through the film's enlisting and repurposing of various modern visual traditions, from photography to film. Most obvious are the references to the theorizations of "the mass ornament" (Siegfried Kracauer), which is here brutally applied to the arrangements of myriad animal carcasses; or the "New Objectivity" via its previous alteration of, for example, Andreas Gursky's digitally manipulated landscapes of late capitalism. Geyrhalter re-locates Gursky's altered real worlds into a reality of distorted social, political and ethical relations. A film such as Alfred Hitchcock's North by Northwest is also indexed to ominous effect. Ultimately, Nöllgen concludes with Val Plumwood that the current "ecological crisis" is due to the failing of reason and culture, and that "both [are] unable to adapt themselves to the earth" (qtd.). Unser täglich Brot counters this rationalized world of production and consumption with a "horror vacui of silence" - as speechlessness - which is meant to question the efficacy of human logos in (re)connecting with the non-human world. 
The faltering of reason, indeed a renewed dialectic of the enlightenment, with all the dangerous socio-political consequences that come when reason turns itself into its own myth, is what Jacobs argues happens when environmental practices such as recycling are internalized, de-historicized and thus carried out with "dogmatic devotion." (qtd) Not only does this irrational sticking to the rules stall environmental improvement, it also becomes the reason and justification on the part of local communities for intolerance towards outsiders. Indeed, as Jacobs shows in her essay in this volume by focusing on the case of Germany, existing models of everyday environmentalism, such as government instituted recycling programs, often require extensive knowledge for effective use. Lacking such knowledge, outsiders are set up for cultural failure. Failing, as Jacobs shows, means that the communities and media are quick to conflate the outsider with dirt, waste, and with that matter out of place that, via Mary Douglas, Kristeva has re-termed the abject. ${ }^{33}$ Though inspired by global guidelines and imagined as accessible to all, environmental practices are cultural-historical phenomena, Jacobs emphasizes. Acquiring or sustaining one's own environmentalism in a new cultural environment therefore requires extensive adaption and learning. In her essay, focusing on media coverage of environmental initiatives aimed at refugees who have come to Germany, Jacobs highlights the cultural-political contradictions that afflict strict environmentalist policies in this country, especially when adopted as integrative measures. Although not explicitly, Jacobs approaches the important environmentalist practice of recycling by considering its biopolitics. She points out how the welcome desire to ameliorate environmental degradation issues regulations and generates practices that must be critically scrutinized since they have the potential "to encourage more intensive interventions in the everyday minutiae of our material lives. For even as we might welcome a broad transformation in lifestyle according to an eco-ethos, the norms, incentives, and identities people adopt inevitably become part of new disciplinary formations whose contours need to be specified and traced."34

${ }^{33}$ See also Sullivan "Dirt Theory and Material Ecocriticism," 515-531.

${ }^{34}$ Diana Coole and Samantha Frost, New Materialisms, 22. 
Krebber's contribution 'Negative Dialectics of Nature: From Nature's Death to New Materialisms" closes this collection with a theoretical proposition and provocation: his article seeks to recover the critical potential of Adorno's concept of negative dialectics for the environmental humanities through a negative dialectical critique of the environmentalist discourse on nature. Applied to ecocriticism's various historical phases and theories, Adorno's negative dialectic allows for an idea of nature to filter through according to which nature bears neither a simple corporeal, nor a traditional incorporeal (metaphysical) character. Rather, nature surfaces as a field of tension marked out and mediated through and through by material and immaterial coordinates. As Krebber explains, his "analysis proceeds in negative terms both on the level of discourse and on that of the object: it negates the ecocritical discourse on nature while at the same time negating a conclusive definition of nature." (qtd) Rather than a solid entity, nature is imagined as a formal principle that appears in an open dialectical movement between instances of material manifestation and presence on the one hand, and immaterial aspects of productivity, agency and change, on the other.

Of Rocks, Mushrooms and Animals: Material Ecocriticism in German-speaking Cultures does not provide perhaps the kinds of reading and writing of the world as text that are surfacing in material ecocriticism since its sustained engagement with the sciences and the environmental humanities. The seven essays in this volume are, in this regard, strictly text-oriented. However, their heterogeneous, ecocritical, textual approaches to literary, cinematic, and theoretical works, including current engaged practices in environmentalism, all highlight the facticity of nature through its agentic creativity, and its cultural instability.

All contributions, each from a distinctive angle, respond to several of the most pressing sociocultural and political concerns to which material ecocriticism has committed itself. Among these issues, the authors in this collection consider agency from the perspective of the creative co-constitution of human and non-human subjects; they discuss affective modalities of being in the world that are grounded in the sharing of the reciprocal vulnerabilities of human and non-human nature; they ponder the resistance to developing non-anthropocentric 
experiences or cognitive practices of living in the world that may come from individual and collective memory-work; they critique the brutality of biopolitics in the age of industrial farming; and, last but not least, from the same biopolitical viewpoint they dissect the contradictions that emerge within environmental policies from their unreflected, dogmatic applications.

In her own edited book, New International Voices in Ecocriticism, Oppermann wishes to open the field to less established scholars and to all those voices that can bring different cultural and historical experiences to bear on the concerns raised and examined in ecocriticism. This present publication acts on that call by welcoming a younger generation of ecocritics who hope that their own distinctive investments in the naturecultures that make up this world will be less of an academic distraction than a work of diffraction. ${ }^{35}$

\section{Works Cited}

Agamben, Giorgio. The Open: Man and Animal. Palo Alto: Stanford University Press, California, 2004

Alaimo, Stacy. Bodily Natures: Science, the Environment and the Material Self. Bloomington: Indiana University Press, 2010 Beevors, Michele. "The Wreck of Hope." In Catalogue of the eponymous exhibition in Oamaru, NZ at the Forrester Gallery, 12 December 2014 - February 2015

\footnotetext{
${ }^{35}$ Just a final comment about the formatting of the volume. Because each essay will be made available individually online, the editors decided to let each author choose his or her referencing style.
} 
Buell, Lawrence, Ursula K. Heise and Karen Thornber. "Literature and Environment." The Annual Review of Environment and Resources 36 (2011): 417-440

Coole, Diana and Frost Samantha, eds. New Materialisms: Ontology, Agency, and Politics. Durham, NC and London: Duke University Press, 2010

Dolphijn, Rick and Iris van der Tuin. New Materialism: Interviews and Cartographies. Ann Arbor: Open Humanities Press, 2012

Gaard, Greta. "Mindful New Materialisms: Buddhist Roots for Material Ecocriticism's Flourishing." In Material Ecocriticism, edited by Serenella Iovino and Serpil Oppermann, 291-300. Bloomington: Indiana University Press, 2014

Garrard, Greg. Ecocriticism. London: Routledge, 2012

Ginn, Franklin, Uli Beisel and Maan Barua. "Flourishing with Awkward Creatures." Environmental Humanities 4 (2014): 113-123

Goodbody, Axel. "Heimat and the Place of Humans in the World: Jenny Erpenbeck's Heimsuchung in Ecocritical Perspective." New German Critique 43 (October 2015): 1-27

Goodbody, Axel and Kate Rigby, eds. Ecocritical Theory: New European Approaches. Charlottesville and London: University of Virgina Press, 2011

Haraway, Donna. "Staying with the Trouble: Xenoecologies of Home for Companions in the Contested Zones." Cultural Anthropology website, July 27, 2010. At https://culanth.org/ fieldsights/289-staying- with-the-trouble-xenoecologies-of-home-forcompanions-in-the-contested-zones

Haraway, Donna and Cary Wolfe. "Companions in Conversation." In Manifestly Haraway. Minneapolis and London: University of Minnesota Press, 2016

Harvey, David. Spaces of Hope. Berkeley: University of California Press, 2000

Kirby, Vicky. "Matter out of Place." In What if Culture was Nature all Along? Edited by Vicky Kirby. Edinburgh: Edinburgh Press, 2017

Murphy, Patrick. Literature, Nature and the Other. Albany, NY: SUNY Press, 1995 
Iodicicco Alessandra and Peter Handke. "Handke: Vivo nel bosco, ascolto gli alberi che sussurrano." Il Corriere della Sera, n. d. and n. p. n. online at http://lettura.corriere.it/handke-vivo-nel- boscoascolto-gli-alberi-che-sussurrano/ (accessed on May 8, 2017)

Iovino, Serenella. Besprechungen. At www.academia.edu (accessed on April 30, 2017)

---. "From Thomas Mann to Porto Marghera: Material Ecocriticism, Literary Interpretation, and Death in Venice." In Handbook of Ecocriticism and Cultural Ecology, 349-367. Berlin and Boston: DeGruyter Mouton, 2016

Novero, Cecilia. Antidiets of the Avant-Garde: From Futurist Cooking to Eat Art. Minneapolis and London: University of Minnesota Press, 2010

Oppermann, Serpil. "Introduction." In New International Voices in Ecocriticism, edited by Serpil Oppermann, 1-24. London: Lexington Books, 2015

Richards, Robert J. The Romantic Conception of Life: Science and Philosophy in the Age of Goethe. Chicago: Chicago University Press, 2002

Rigby, Kate. Dancing with Disaster: Environmental Histories, Narratives and the Ethics for Perilous Times. Charlottesville: University of Virginia Press, 2015

---. "Art, Nature and the Poesy of Plants in the Goethezeit: A Biosemiotic perspective." Goethe Yearbook 22 (2015): 23-44

---. "The logos of the living world: Merleau-Ponty, animals and language." Green Letters 18:3 (2014): 332-334

Rutherford, Stephanie. Governing the Wild: Ecotours of Power. Minneapolis and London: University of Minnesota Press, 2011 Schliephake, Christopher. Urban Ecologies: City Space, Material Agency, and Environmental Politics in Contemporary Culture. London: Lexington Books, 2017

Soper, Kate. "Unnatural Times: The Social Imaginary and the Future of Nature." The Sociological Review 57 (2009): 222-235

Sullivan, I. Heather. "Dirty Traffic and the Dark Pastoral in the Anthropocene: Narrating Refugees, Deforestation, Radiation, and Melting Ice." Literatur für Leser 14 (2014): 83-97 
---. "Dirt Theory and Material Ecocriticism." ISLE: Interdisciplinary Studies in Literature and Environment 19:3 (2012): 515-531

Tsing, Anna. "Unruly Edges: Mushrooms as Companion Species." Environmental Humanities 1 (November 2012): 141-54

Westling, Louise. "Literature, the Environment, and the Question of the Posthuman." In Nature in Literary and Cultural Studies: Transatlantic Conversations on Ecocriticism, edited by Catrin Gersdorf and Sylvia Mayer, 25-47. Amsterdam: Rodopi, 2006

Wheeler, Wendy. The Whole Creature: Complexity, Biosemiotics and the Evolution of Culture. London: Lawrence \& Wishart, 2006 Wilke, Sabine. "German Ecocriticism and the Environmental Humanities." GSR 38:3 (2015): 635-652

Williams, Raymond. Marxism and Literature. Oxford and London: Oxford University Press, 1977 


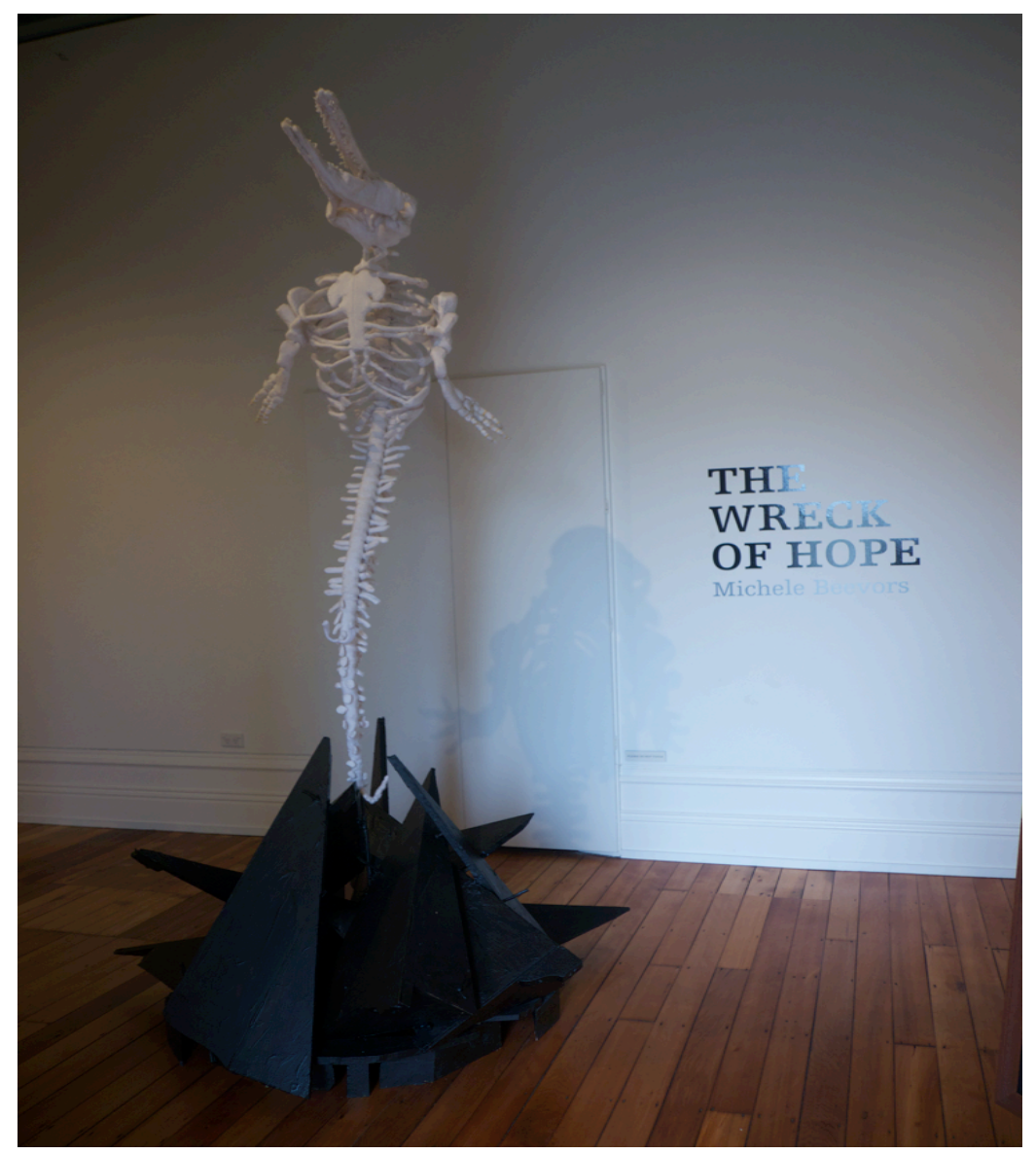

Fig. 1. Beevors, Michele. Wreck of Hope: Delphinus capensis (Dolphin and wardrobe), 2005 - 2017. Mixed Media, $2 \mathrm{mx} 1 \mathrm{mx} 1 \mathrm{~m}$. Courtesy of the Artist. 


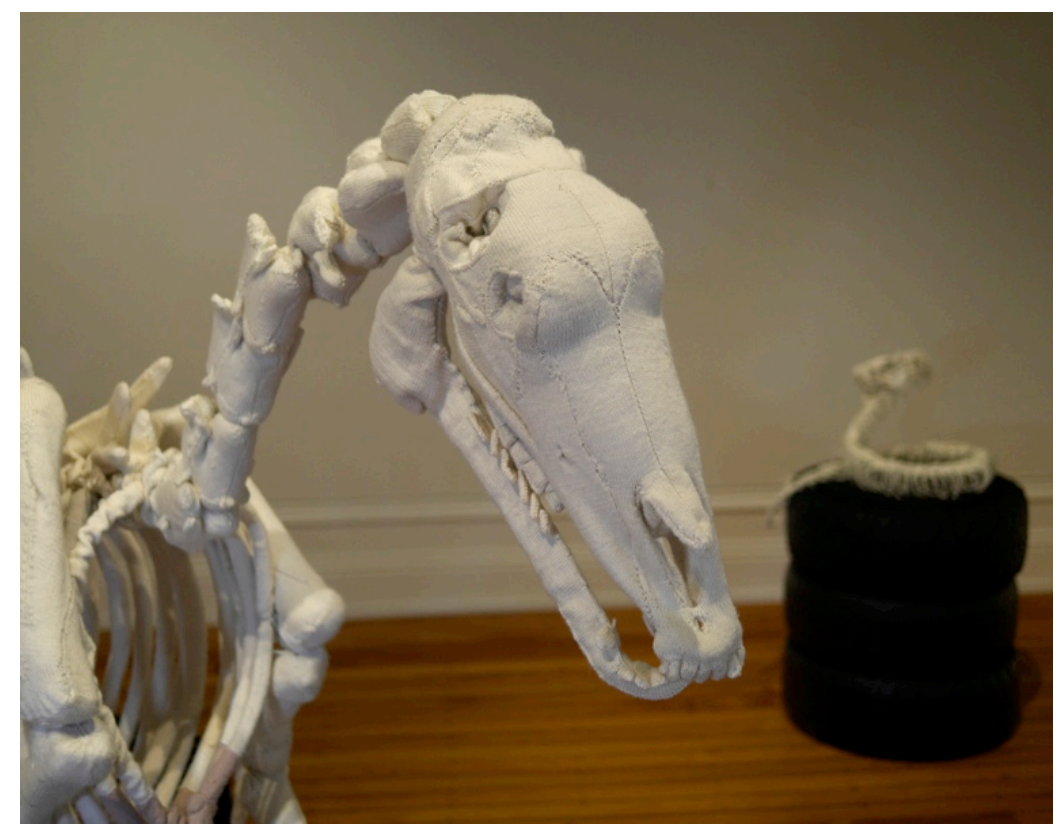

Fig. 2. Beevors, Michele. After Stubbs: Equus ferus caballus (Horse and rider shipwreck) shown here with Run from Fear: Morelia spilota spilota (Snake and truck tires), 2005 - 2017. Mixed Media, 2mx3mx2m. Courtesy of the Artist. 


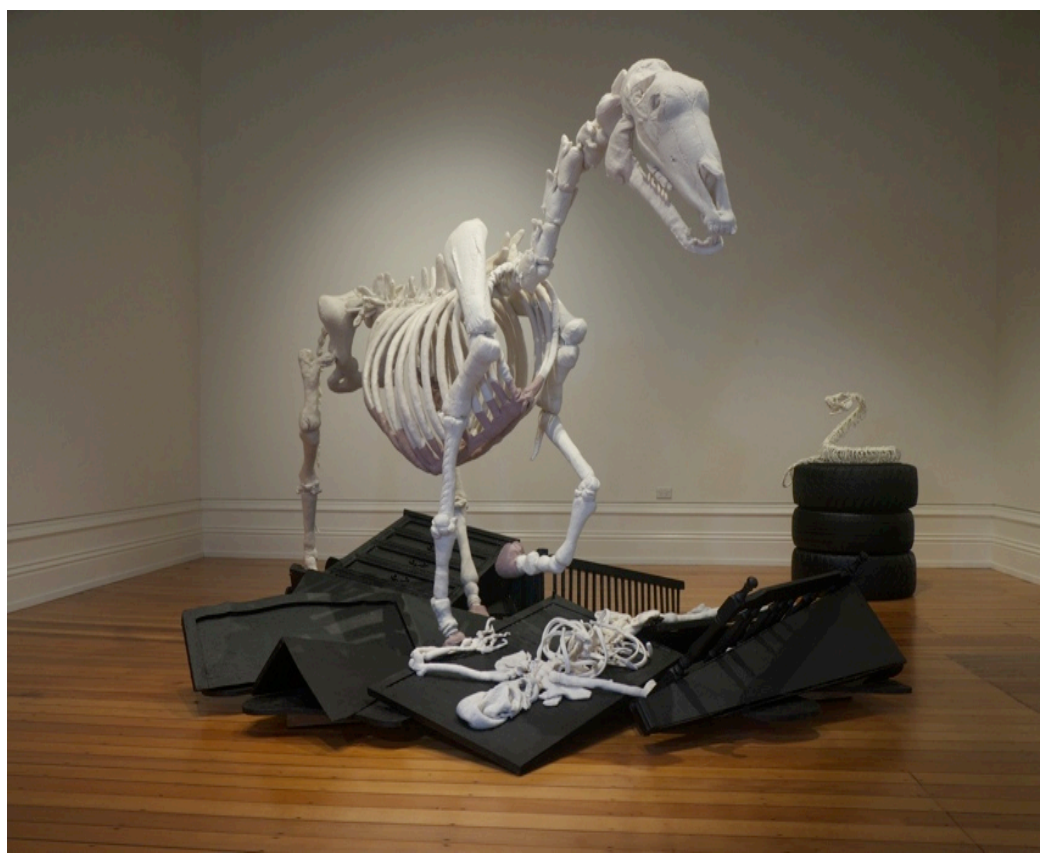

Fig. 3. Beevors, Michele. After Stubbs: Equus ferus caballus (Horse and rider shipwreck) Detail, 2005-2017. Mixed Media, 1mx80cmx80cm. Courtesy of the Artist. 